\title{
A MOBILE PHONE APPLICATION FOR AGRICULTURAL EXTENSION IN MARGINALISED RURAL AREAS OF PONGOLA REGION, ZULULAND DISTRICT, SOUTH AFRICA
}

\author{
Simelane, P. T. ${ }^{1}$, Lall, M. ${ }^{2}$ and Kogeda, O. P. ${ }^{3}$ \\ Correspondence Author: M. Lall, Email: $\underline{\text { lallm@tut.ac.za }}$
}

\begin{abstract}
Subsistence farming plays a pivotal role in the socio-economic development and food security of rural populations. Strategic application of information and communication technology (ICT) to agriculture industry offers great opportunities for economic growth and poverty alleviation. The aim of this work is to implement a mobile solution that provides a platform to enable both extension officers to communicate information on agricultural extension and collaborate on farming and irrigation techniques. In addition, the mobile phone application would assist in sharing market related information for buying, selling of their produce, weather, and finance related services, as well as training and employment opportunities. Being better informed, the local farming community would be able to make decisions that would ultimately lead to an improvement in their socio-economic conditions. Thus, a survey was conducted with 93 farmers selected by random sampling in the Pongola region of Zululand district to establish the penetration of mobile phones. It was found that $94.6 \%$ of the farmers owned mobile phones varying in capabilities from simple to smart phones. Based on the findings of the survey, mobile phone application using Java platform was developed and deployed to the cloud. The users expressed satisfaction with the features and the functionalities of the developed system.
\end{abstract}

Keywords: Mobile phone application, mobile phones, information sharing, subsistence farming, extension officers

\section{INTRODUCTION}

More than a third of the South African population live in rural areas and rely predominantly on agriculture for its sustainable development. South Africa has a dual agriculture economy, with a well-developed commercial farming sector and the subsistence-based communal activities in rural areas (Cousins, 2016:137; Sandrey \& Vink, 2008:223). According to the Department of Agriculture, Forestry and Fisheries (DAFF, 2014), over 50\% of the total land in South Africa is used for agriculture and forestry and its contribution to the South African economy is highly significant. Agriculture contributes 2.0\% of the Gross Domestic Product (GDP) and over 14\% to employment in South Africa. Despite its relatively small share of the total GDP, primary agriculture is an important sector in the South African economy. Agriculture remains a significant provider of employment, especially in the rural areas (DAFF, 2014).

The majority of the rural population are engaged in subsistence farming for their livelihood. The output of these farming activities is mainly to meet its local requirements with little or no

\footnotetext{
${ }^{1}$ Department of Computer Science, Tshwane University of Technology, SimelanePT@ $@$ tut.ac.za.

${ }^{2}$ Department of Computer Science, Tshwane University of Technology, Lallm@tut.ac.za.

${ }^{3}$ Department of Computer Science, Tshwane University of Technology, KogedaPO@tut.ac.za.
} 
S. Afr. J. Agric. Ext.

Vol. 47 No. 1, 2019: 137 - 150

http://dx.doi.org/10.17159/2413-3221/2019/v47n1a495
Simelane, Lall \&

Kogeda

(License: CC BY 4.0)

surplus for trading. The subsistence farmers largely apply traditional farming methods, which are predominantly rain-fed, and have low yields per unit area cultivated (Muyanga \& Jayne, 2014:100; Thamaga-Chitja \& Morojele, 2014:148). In addition, subsistence farmers are often limited in knowledge related to various farming techniques, prevalent market conditions, and financial support. All these factors affect the socio-economic conditions of the rural subsistence farmers (Abro, Alemu \& Hanjra, 2014:465; Rodríguez-Pose \& Hardy, 2015:15). Dissemination of the right information at the appropriate time among farmers is key to providing change in agriculture (Asiedu-Darko, 2013:37). It is therefore of paramount importance to provide a platform that allows the subsistence farmers to engage with one another on these very crucial matters. In addition, such a platform would allow the extension officers to communicate and extend support to the subsistence farmers. It has been reported that information and communication technologies (ICTs) in general, and mobile technologies in particular, have the potential to positively influence the socio-economic conditions of a population (Maumbe \& Okello, 2013:115; Smith \& Charen, 2011:49; Zyl et al., 2014:4).

In its report, the World Bank (2008) suggests that $98 \%$ of the South African population live in areas covered by mobile cellular signal. It is evident from the aforementioned statistics that the availability of mobile connectivity should no longer be viewed as a limitation when contemplating providing mobile information services in South Africa. This holds particularly true in the context of South African subsistence farming commonly practiced in marginalised areas with relatively low fixed line telecommunication, low internet connectivity, and poor road infrastructure (Malusi \& Kogeda, 2013:1; Simelane, Kogeda \& Lall, 2015:120). Using mobile phones can improve access to information, reduce the cost of searching for information, and improve co-ordination between various parties and increase market efficiency (Aker \& Mbiti, 2010:210).

The strategic application of ICT to the agricultural industry offers a great opportunity for economic growth and poverty alleviation (Qiang et al., 2012:32). Food security is paramount for the survival of individuals, families and ultimately the whole nation. The role that ICT can play in addressing these challenges is increasing as personal ICT devices such as mobile phones or tablets are becoming more widely adopted in day-to-day activities. Mobile technology is rapidly being adopted as the technology of choice for delivery of ICT services and solutions (Aker, 2011:634). From a socio-economic point of view, mobile telephones effectively reduce the "distance" between individuals and institutions, making the sharing of information and knowledge easier and more effective (Wei \& Zhang, 2008:172). In the framework of agriculture development, the role of ICT can be viewed as a three-staged process (Figure 1). 


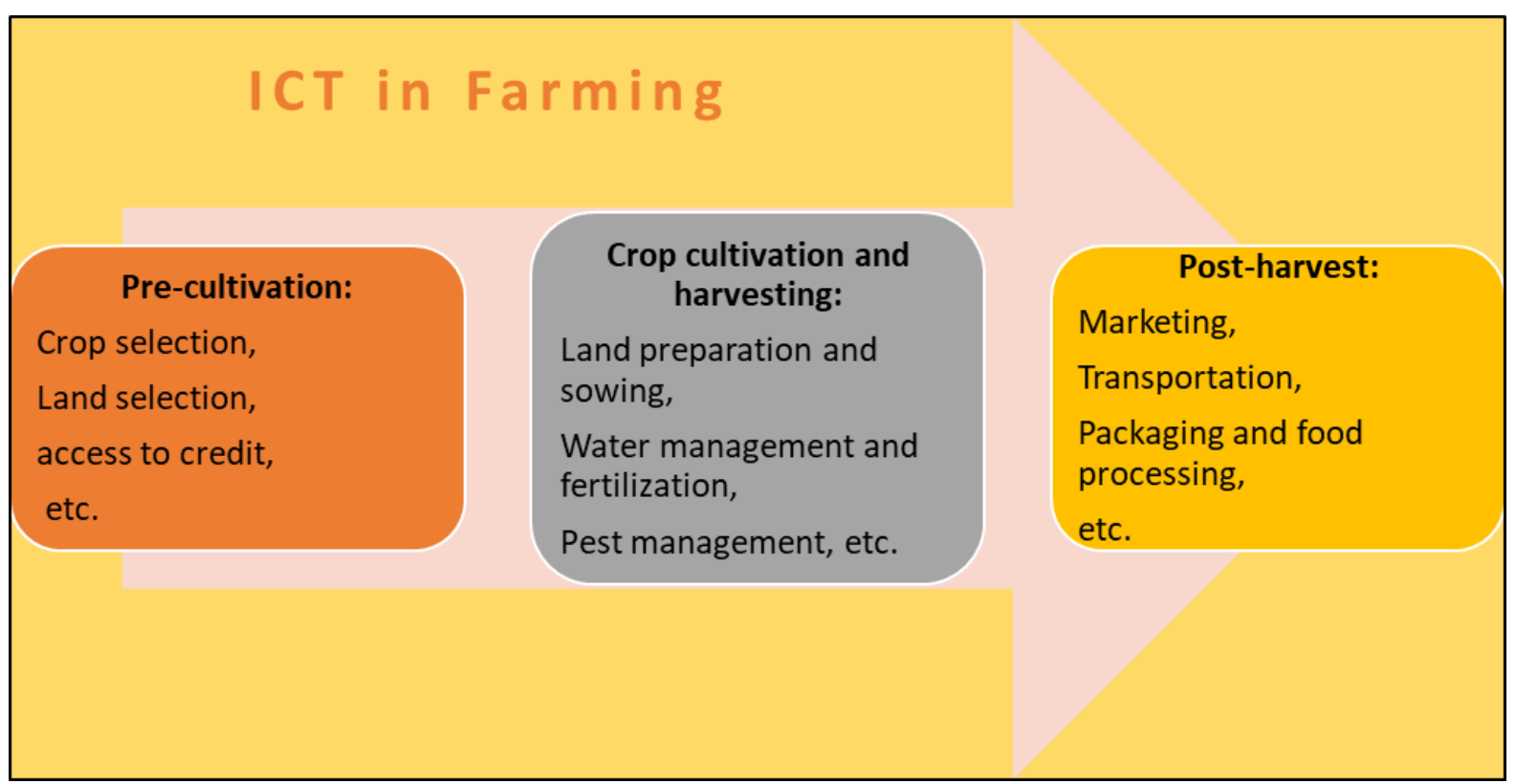

Figure 1: Role of ICT in various stages of farming (adopted from Zyl et al., 2014:6)

In the pre-cultivation stage, ICT can assist, for example, with providing or sharing information related to crop selection, land selection, and access to credit facilities. During the cultivation and harvesting phase, ICT could be used for sharing techniques related to land preparation, sowing, and irrigation techniques. Similarly, in the post-harvesting stage, ICT could be useful in sharing information related to marketing, transportation, packaging, and food processing. In all these stages, the role of extension officers is important to subsistence farmers in enhancing their farming yields and standard of living.

Extension in the context of agriculture, is employed by agricultural organisations to assist farmers in improving agricultural output through provision of relevant and current information. Agricultural extension officers advise and assist farmers in their decision making, strategic planning and stimulate desirable agricultural developments (Fu \& Akter, 2012:5; Simpson \& Calitz, 2014:99). The nature of information shared through extension services includes information such as innovations in crop varieties, pest management, soil fertility, current market conditions, weather forecasting, and best practices in agriculture (Khapayi \& Celliers 2016:38; Oladele, 2015:31; Simpson \& Calitz, 2014:99). In recent years, agricultural extension and advisory services has seen many changes. A noticeable change that has taken place is the philosophy and rationale behind the move towards more participatory approaches and participatory technology development for providing extension services and the role of extension services in the broader information and knowledge sharing processes (Leeuwis, 2004:118).

\section{PURPOSE, OBJECTIVE AND SIGNIFICANCE OF THE STUDY}

The purpose of this study was to ascertain the penetration of mobile phones amongst the subsistence farming community of rural Pongola region, KwaZulu-Natal. The objective was to develop a mobile phone application platform that could assist the local farming community and the extension service providers to collaborate and share information related to various facets 
S. Afr. J. Agric. Ext.

Vol. 47 No. 1, 2019: 137 - 150

http://dx.doi.org/10.17159/2413-3221/2019/v47n1a495
Simelane, Lall \&

Kogeda

(License: CC BY 4.0)

of farming. This could include extension services such as weather related information, information pertaining to farming tools and techniques, as well as information regarding seeds, fertilizers, and irrigations. In addition, the mobile phone application could provide information related to financial support, bursary schemes and job opportunities available to the local farming community. It is envisaged that such an application would provide a platform to facilitate cooperation and sharing of information not only amongst the subsistence farmers but also between subsistence farmers and the more successful commercial farmers in that area. It is hoped that by cooperating and sharing of good farming practices and other information of mutual interests that the rural farming communities would be able to improve their socioeconomic conditions.

\section{METHODOLOGY}

To achieve the research purpose and objective, both qualitative and quantitative data were collected using semi-structured interviews and questionnaires from 93 randomly selected farmers situated in Pongola area. Pongola, also known locally as uPhongolo, is a small region located in northern KwaZulu-Natal, South Africa. Pongola Municipality area is largely an oldstyle area with its tribal land patterns and high density marginalised rural settlements. The economy of Pongola is based mainly on sugarcane farming.

The data gathering methods/techniques applied were predominantly face-to-face interviews and structured questionnaires. The data collected were used in the design and development of the mobile phone application. The mobile phone application was modelled using the Unified Modelling Language (UML). The cloud architecture was used to promote availability of the system. The application was developed on Java platform. MySQL version 5.0.27 database was selected as a repository for storing farming related information. Apache Tomcat 6.0 was chosen as the server to host the application. Java was used as it enables cross-platform deployment of the application and MySQL database was selected as it is an open source database management tool with support for security, reliability and scalability. The choice of Apache Tomcat was because it is a free, open source web server that is easy to use and install.

A high-level architectural view of our application is presented in Figure 2. Farmers can download and upload information from the cloud server. This information could be in the form of text or pictures on any topic of interest to the local farming communities. Various web services such as weather web service are installed on the server. Access to the server is through mobile network services. A firewall is installed to enhance security of the system. 
S. Afr. J. Agric. Ext.

Vol. 47 No. 1, 2019: 137 - 150

http://dx.doi.org/10.17159/2413-3221/2019/v47n1a495
Simelane, Lall \&

Kogeda

(License: CC BY 4.0)

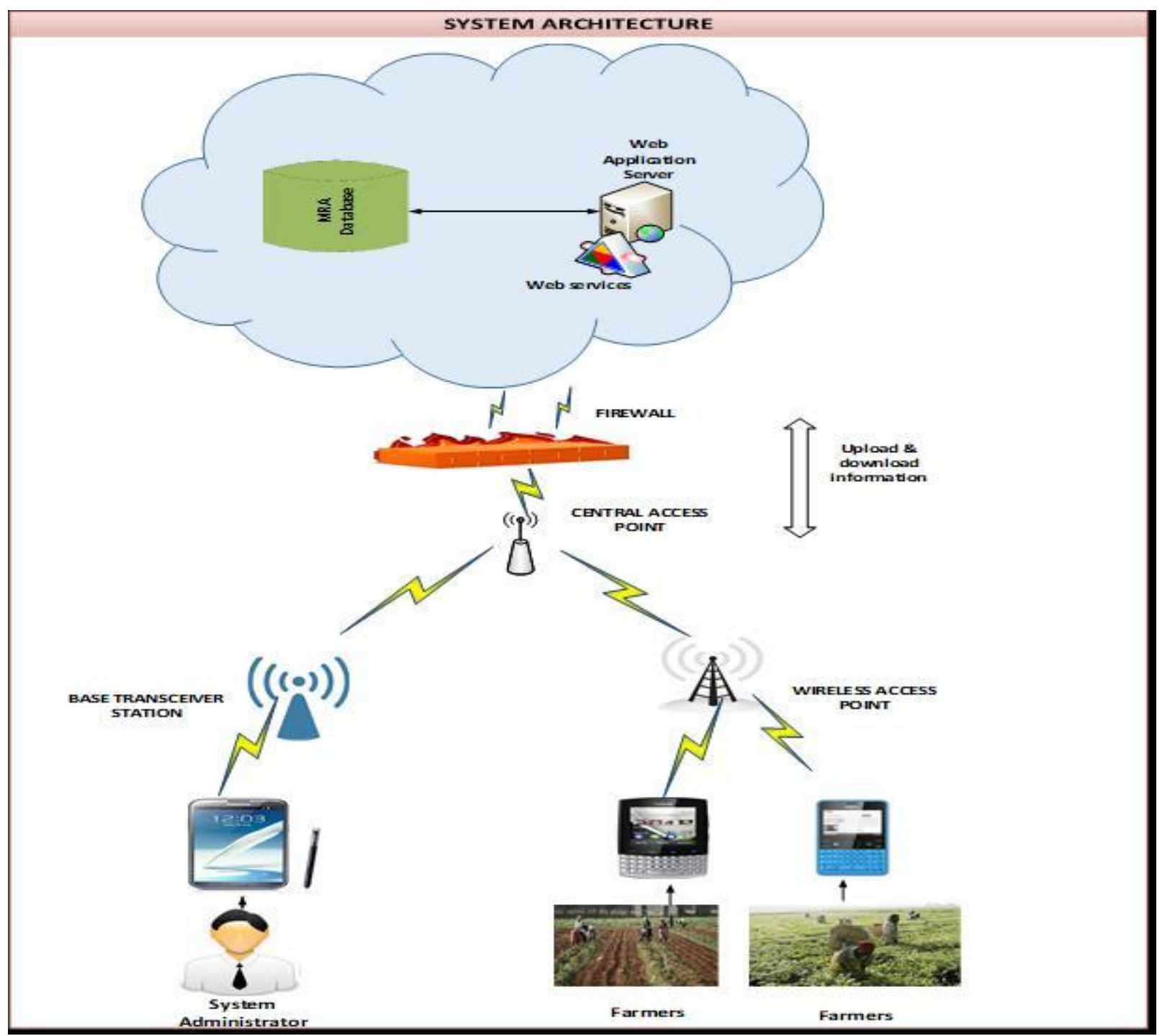

Figure 2: An overview of the mobile phone application system architecture (Simelane et al., 2016:258).

\section{RESULTS AND DISCUSSION}

\subsection{Scale of farming, sex and age}

A descriptive analysis of the sample data revealed that $96.8 \%$ of the farmers practiced subsistence farming and the remaining 3.2\% were commercial farmers. Males formed $46.2 \%$ of the study group. Figure 3 shows the age distribution of both the male and female farmers. It was observed that $43 \%$ of the participants were under the age of 35 years. 
S. Afr. J. Agric. Ext.

Vol. 47 No. 1, 2019: 137 - 150

http://dx.doi.org/10.17159/2413-3221/2019/v47n1a495
Simelane, Lall \&

Kogeda

(License: CC BY 4.0)

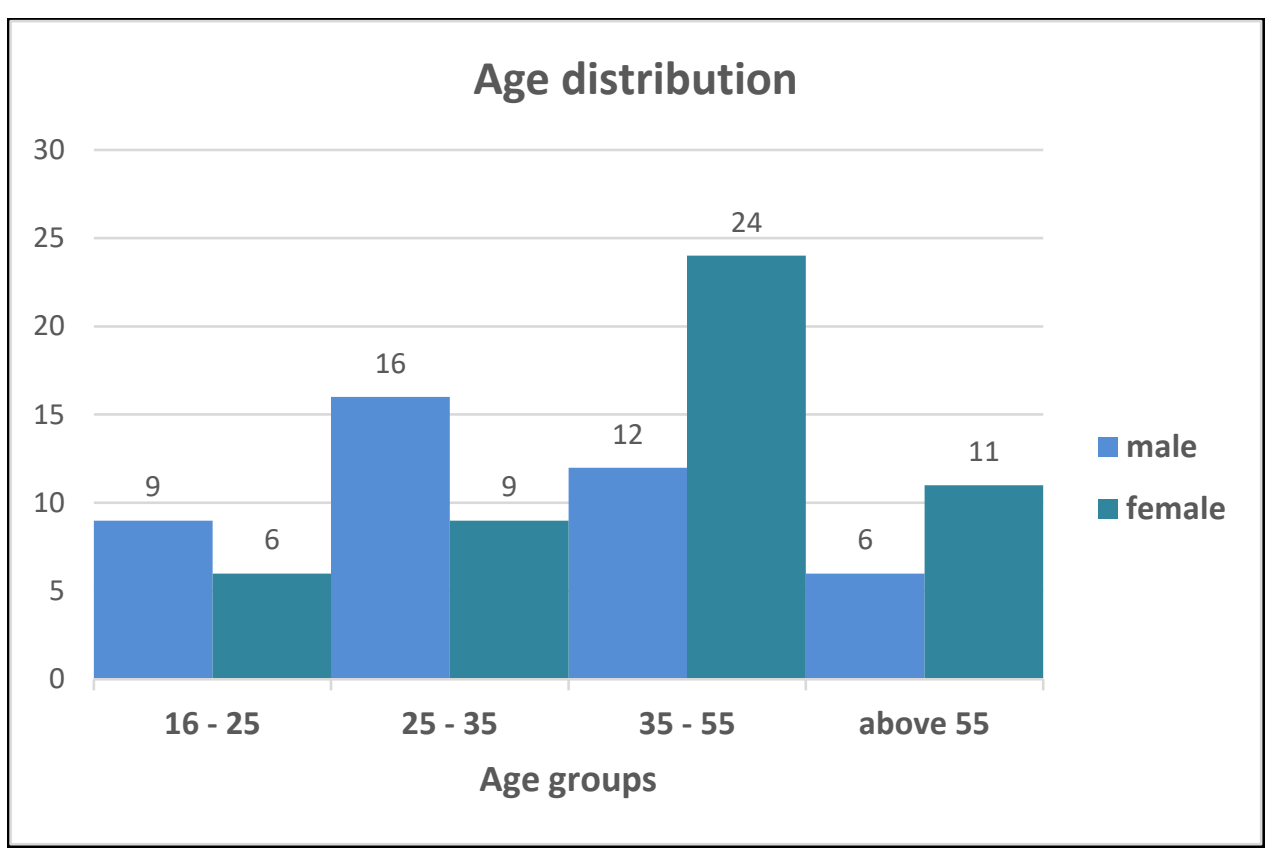

Figure 3: Age distribution of sampled farmers in Pongola area.

\subsection{Formal education}

It was found that $47.3 \%$ of the participants had completed matric or a higher qualification. The breakdown of the educational levels is shown in Figure 4. In addition, it was observed that $78.5 \%$ of the participants could communicate fairly well in English.

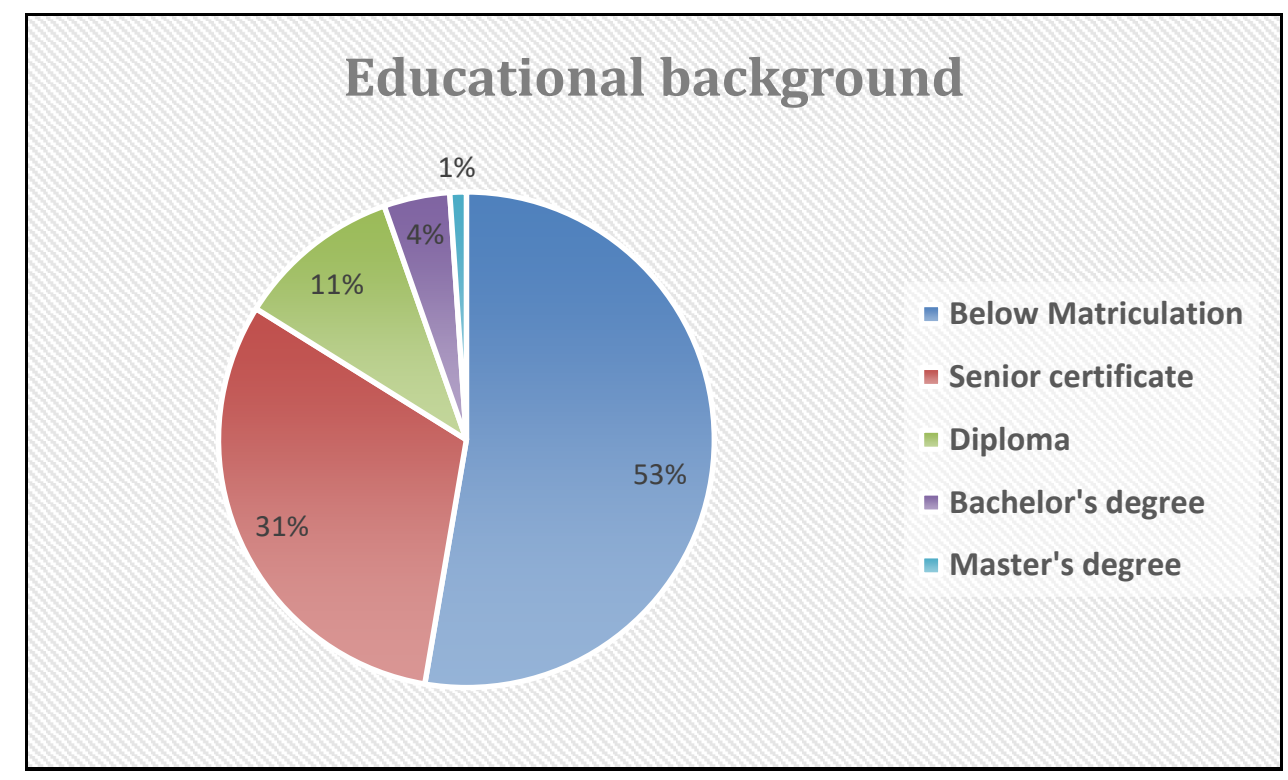

Figure 4: Educational background of the participants. 
S. Afr. J. Agric. Ext.

Vol. 47 No. 1, 2019: 137 - 150

http://dx.doi.org/10.17159/2413-3221/2019/v47n1a495
Simelane, Lall \&

Kogeda

(License: CC BY 4.0)

\subsection{Farm sizes}

It was found that $93.5 \%$ of the farmers had less than one hectare of land to cultivate for sustaining themselves and their families. The pie chart (Figure 5) depicts the land size distribution amongst the farming community.

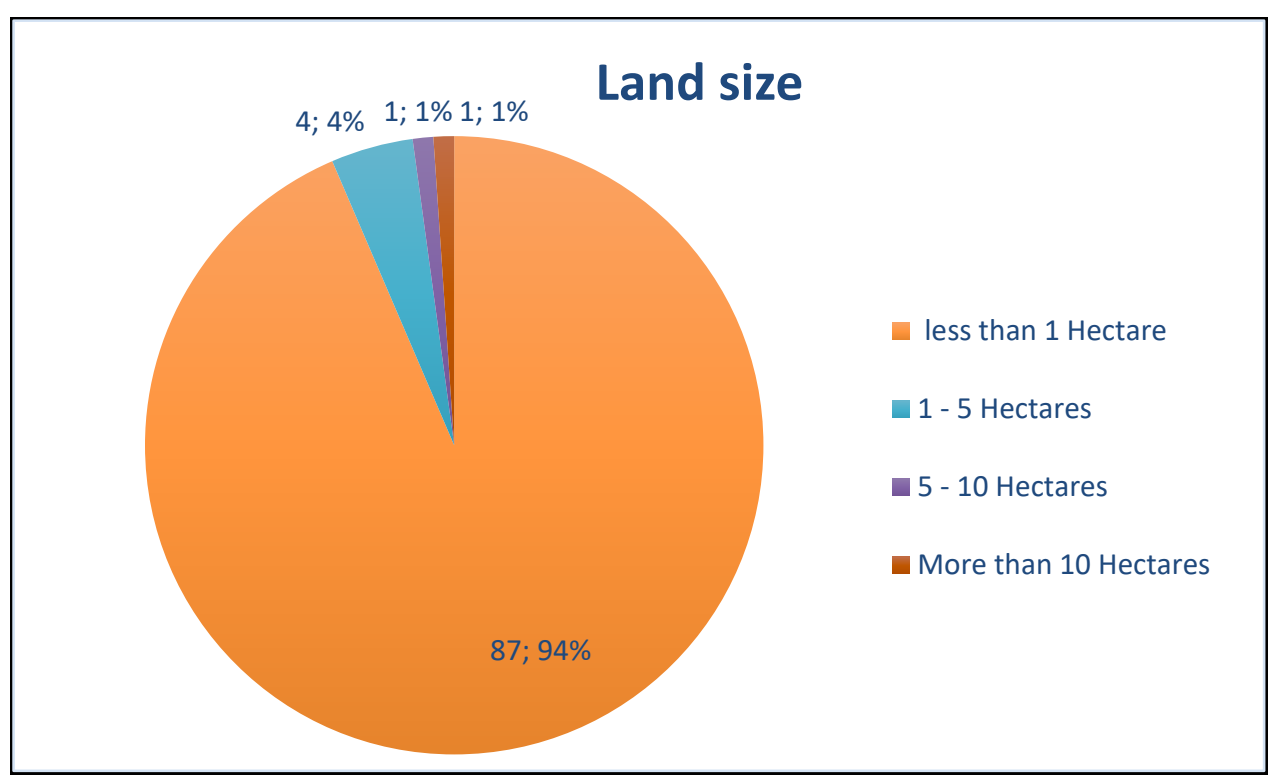

Figure 5: Land size distribution

From the data presented in Figure 5, it can be deduced that there is a sizable number of young people who are fairly well educated but with little land to support themselves and their families. Based on these observations, the mobile phone application was developed to enable the farming community of Pongola to share information that could assist in improving farm yields, share opportunities such as those provided by the government, and to improve their economic conditions. When asked about the communication devices owned, $94.6 \%$ of the farmers indicated that they possessed mobile phones. The types of mobile phones owned is depicted in Table 1. In addition, it was established that $43.2 \%$ (38) of the farmers had simple phones and the remaining 56.8\% (50) had feature/smart phones. A simple phone, such as Nokia 100, is essentially for making calls and sending text messages. In addition, it may have a simple camera (with low pixels). Although a simple phone does not have features such as email capabilities or video recordings, it does have a very good battery life. Smartphones, in contrast, are more like miniature computers and perform many of the same tasks as tablets and desktop computers while offering the same basic phone features found on standard simple phones. The high percentage $(94.6 \%)$ of phones owned by the farming community lends itself as a suitable platform for the dissemination of agricultural extension information. For example, the extension agents could send bulk messages to a group of farmers informing them of an upcoming training opportunity. 
S. Afr. J. Agric. Ext.

Vol. 47 No. 1, 2019: 137 - 150

http://dx.doi.org/10.17159/2413-3221/2019/v47n1a495
Simelane, Lall \&

Kogeda

(License: CC BY 4.0)

Table 1: Types of phones owned

\begin{tabular}{|l|l|l|}
\hline Make of Phones & Frequency & Percentage \\
\hline Nokia & 62 & 70.4 \\
\hline Samsung & 14 & 15.9 \\
\hline Blackberry & 10 & 11.4 \\
\hline Others & 2 & 2.3 \\
\hline
\end{tabular}

The decision to develop the mobile phone application using Java was supported by the fact that several mobile phones operating on various operating systems were in use by the farming community. It was therefore essential that the developed mobile phone application be portable to these platforms with minimal changes to the code. Figure 6 shows the main menu of the mobile application after a user has logged in successfully. It highlights the features available to the farmers and the extension agents.

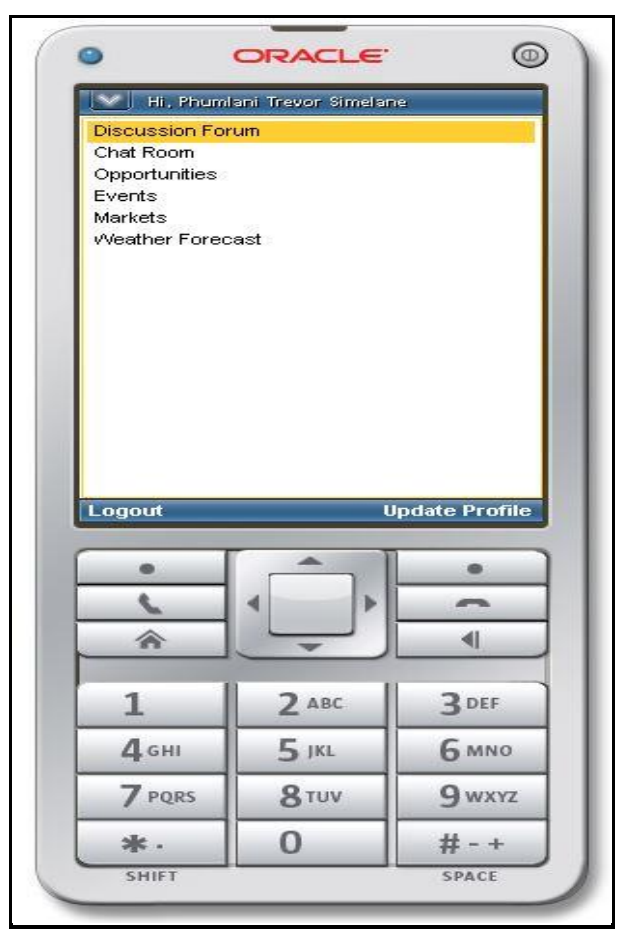

Figure 6: Main features of the developed mobile phone application.

The discussion forum sub-menu enables farmers to post questions and receive suggestions on a particular topic. In addition, users can upload photos in support of their discussions. The chat room sub-menu allows one person to communicate with another. The main difference between the discussion forum and chat room services is that in chat room, the communication is between two individuals where as in discussion forum, many users can communicate simultaneously on a particular topic under discussion (Figure 7). 
S. Afr. J. Agric. Ext.

Vol. 47 No. 1, 2019: 137 - 150

http://dx.doi.org/10.17159/2413-3221/2019/v47n1a495
Simelane, Lall \&

Kogeda

(License: CC BY 4.0)

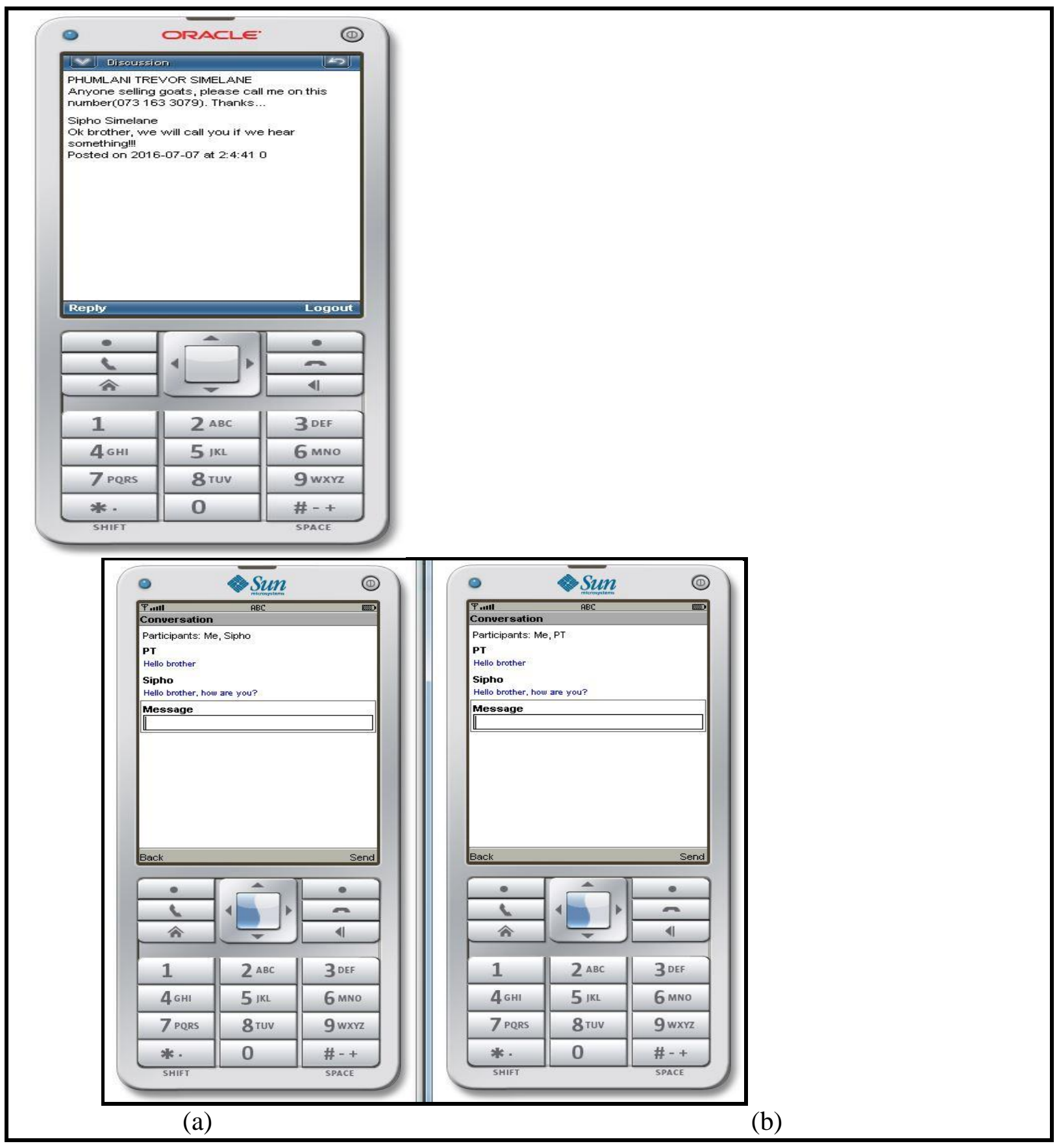

Figure 7: Screenshot of Discussion forum (a) and chat services between two individual (b).

The Opportunity sub-menu allows individuals to post information related to bursaries, jobs and financial aid opportunities available to the local farming community. 
S. Afr. J. Agric. Ext.

Vol. 47 No. 1, 2019: 137 - 150

http://dx.doi.org/10.17159/2413-3221/2019/v47n1a495

Simelane, Lall \&

Kogeda

(License: CC BY 4.0)

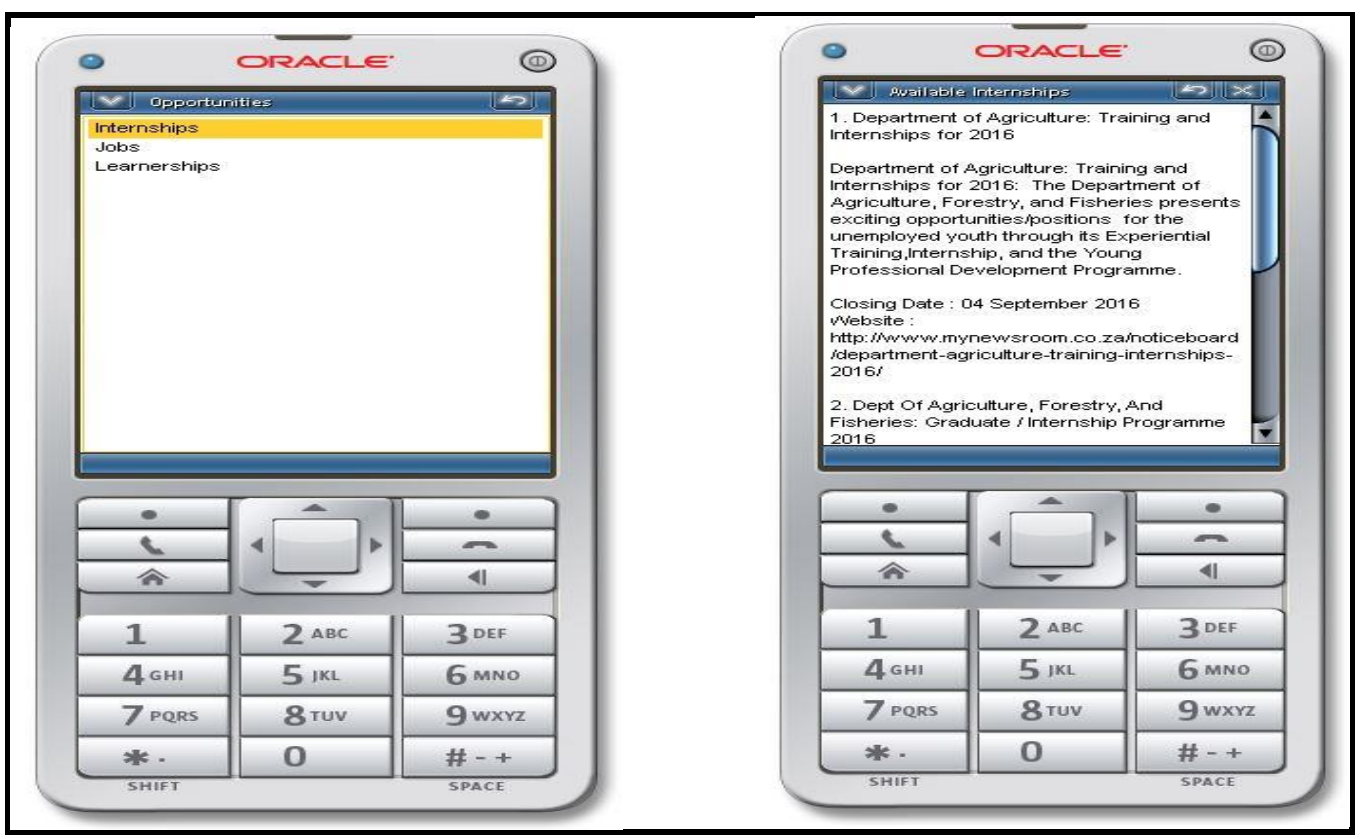

Figure 8: Screenshot of internship opportunities for the local community.

The events sub-menu draws attention to information related to an event of interest to the local farming community. The markets sub-menu holds information related to interests such as pricing, marketing and transportation. Figure 9 shows the weather forecast sub-menu offering the weather related services. 
S. Afr. J. Agric. Ext.

Vol. 47 No. 1, 2019: 137 - 150

http://dx.doi.org/10.17159/2413-3221/2019/v47n1a495
Simelane, Lall \&

Kogeda

(License: CC BY 4.0)

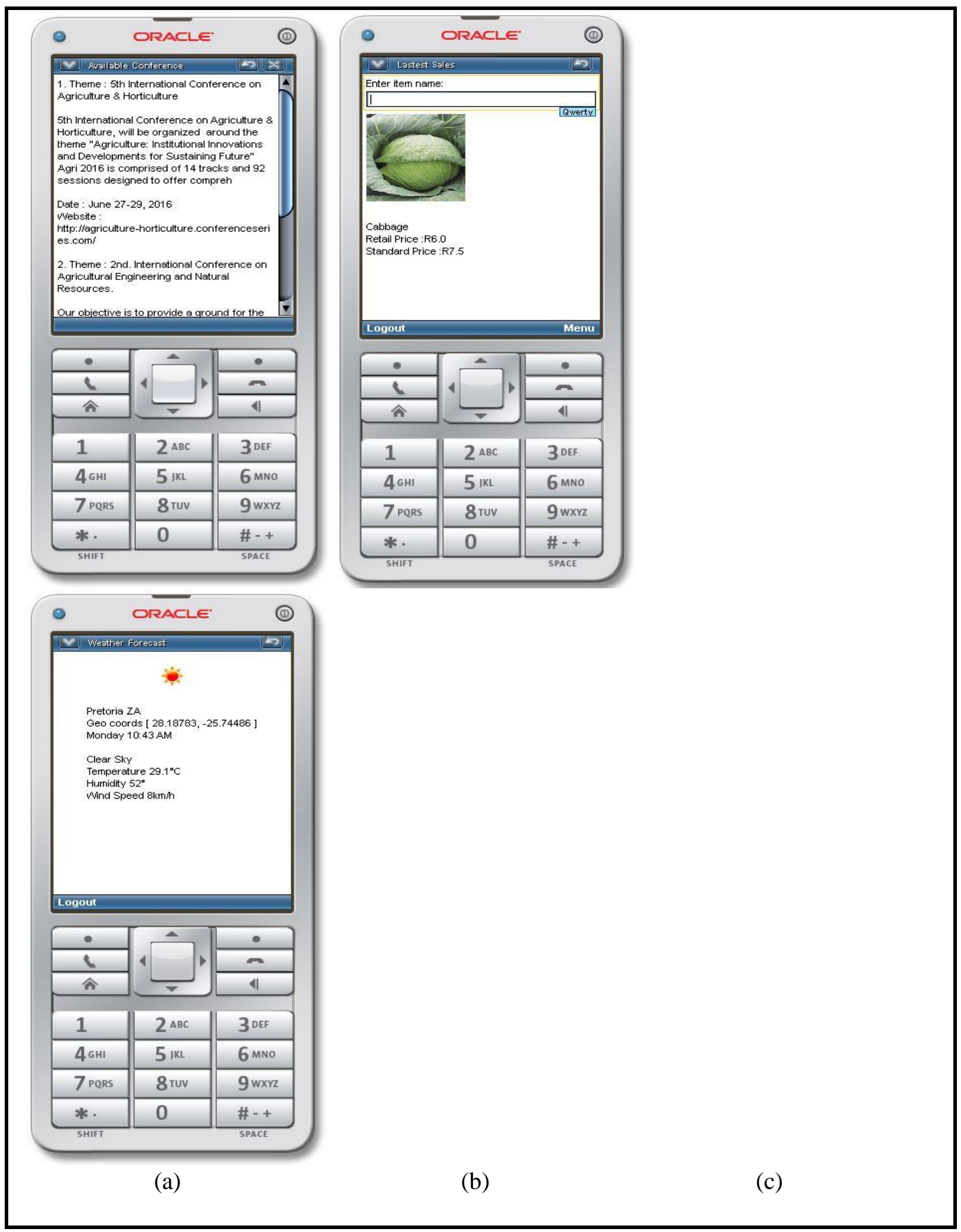

Figure 9: Screenshots of local events (a), market information (b), and weather services (c).

The developed mobile application was evaluated for its usability using the Heuristic evaluation technique. The findings are reported in Simelane et al., (2016). The farmers expressed their 
S. Afr. J. Agric. Ext.

Vol. 47 No. 1, 2019: 137 - 150

http://dx.doi.org/10.17159/2413-3221/2019/v47n1a495
Simelane, Lall \&

Kogeda

(License: CC BY 4.0)

deep satisfaction with the application stating that it would not only help them in their daily farming activities but should also be deployed to other farming communities across the country.

\section{CONCLUSIONS AND RECOMMENDATIONS}

A little less than half of the farmers in rural Pongola, KwaZulu-Natal are young, fairly well educated but with very small land to support themselves and their families. It was observed that most of the farmers owned mobile phones. Since both simple and smart/feature phones were used in large percentages, Java was used for the mobile phone application development. Due to the broad cellular coverage across the country, the prospects of making use of mobile phones as a platform for sharing and delivering of extension services was exploited. It is recommended that the adoption of such mobile phone applications be explored by government agencies to promote delivery of extension services. Future work should extend the application to include support for isiZulu, the predominant language spoken in the area. Additional features that would facilitate and encourage extension officers to interact and provide services to their local subsistence farming community should also be included in the application.

\section{ACKNOWLEDGMENTS}

The authors are grateful to the members of Pongola farming community for their voluntary participation in this study. A special gratitude to the NRF for the financial support (Grant No. 94169) and Tshwane University of Technology for granting the ethical clearance certificate (FREC/ICT/2014/06/001) to conduct this study.

\section{REFERENCES}

ABRO, Z.A., ALEMU, B.A. \& HANJRA, M.A., 2014. Policies for agricultural productivity growth and poverty reduction in rural Ethiopia. World Dev., (59):461-474.

AKER, J.C., 2011. Dial "A" for agriculture: a review of information and communication technologies for agricultural extension in developing countries. Agric. Econ., 42(6):631-647.

AKER, J.C. \& MBITI, I.M., 2010. Mobile phones and economic development in Africa. $J$. Econ. Perspect., 24(3):207-232.

ASIEDU-DARKO, E., 2013. Agricultural extension delivery in Ghana: A case study of factors affecting it in Ashanti, Eastern and Northern regions of Ghana. J. Agric. Ext. Rural Dev., 5(2):37-41.

COUSINS, B., 2016. Land reform in South Africa is failing. Can it be saved? Transformation: Critical Perspectives on Southern Africa, 92(1):135-157.

DEPARTMENT OF AGRICULTURE, FORESTRY AND FISHERIES (DAFF), 2014. Economic review of the South African agriculture. Department of Agriculture, Forestry and Fisheries, Pretoria.

FU, X. \& AKTER, S., 2012. Impact of mobile telephone on the quality and speed of agricultural extension services delivery: Evidence from the rural e-services project in India. In 
Proceedings of International Association of Agricultural Economists (IAAE) 2012Triennial Conference (pp. 18-24).

KHAPAYI, M. \& CELLIERS, P.R., 2016. Factors limiting and preventing emerging farmers to progress to commercial agricultural farming in the King William's Town area of the Eastern Cape Province, South Africa, S. Afr. J. of Agric. Ext., 44(1):25-41.

LEEUWIS, C., 2004. Communication for rural innovation: Rethinking agricultural extension. 3rd ed. Blackwell Science Inc.

MALUSI, Y. \& KOGEDA, O., 2013. A mobile transport scheduling and coordination system for marginalized rural areas. In The Proceedings of 15th Annual Conference on WWW Applications (pp. 10-13).

MAUMBE, B.M. \& OKELLO, J.J., 2013. Uses of information and communication technology (ICT) in agriculture and rural development in sub-Saharan Africa: Experiences from South Africa and Kenya. International Journal of ICT Research and Development in Africa, 1(1):113-134.

MUYANGA, M. \& JAYNE, T., 2014. Effects of rising rural population density on smallholder agriculture in Kenya. Food Policy, (48):98-113.

OLADELE, O., 2015. Effect of information communication technology (ICT) on agricultural information access among extension officers in North West Province South Africa. $S$. Afr. J. Agric. Ext., 43(2):30-41.

QIANG, C.Z., KUEK, S.C., DYMOND, A. \& ESSELAAR, S., 2012. Mobile applications for agriculture and rural development. World Bank, Washington.

RODRÍGUEZ-POSE, A. \& HARDY, D., 2015. Addressing poverty and inequality in the rural economy from a global perspective. Appl. Geogr., (61):11-23.

SANDREY, R. \& VINK, N., 2008. Deregulation, trade reform and innovation in the South African agricultural sector: Trade and innovation project-case No. 4 (No. 76). OECD Publishing.

SIMELANE, P.T., KOGEDA, O.P. \& LALL, M. 2015., A cloud computing augmenting agricultural activities in marginalized rural areas: A preliminary study. In Emerging Trends in Networks and Computer Communications (ETNC), International Conference (pp. 119-124).

SIMELANE, P.T., KOGEDA, OP., LALL, M \& KALEMA, B.M., 2016. A cloud computing model for augmenting agricultural activities in marginalized rural areas in developing countries. Asian Journal of Information Technology, 16(2):255-267.

SIMPSON, A. \& CALITZ, A., 2014. The use of mobile technologies amongst South African commercial farmers. S. Afr. J. Agric. Ext., 42(1):98-107.

SMITH, W.M. \& CHAREN, S., 2011. Geospatial BI: How businesses are keeping pace with mobile customers. Business Intelligence Journal, 16(2):44-55. 
S. Afr. J. Agric. Ext.

Vol. 47 No. 1, 2019: 137 - 150

http://dx.doi.org/10.17159/2413-3221/2019/v47n1a495
Simelane, Lall \&

Kogeda

(License: CC BY 4.0)

THAMAGA-CHITJA, J.M. \& MOROJELE, P., 2014. The context of smallholder farming in South Africa: Towards a livelihood asset building framework. J. Hum. Ecol., 45(2):147-155.

WEI, L. \& ZHANG, M., 2008. The adoption and use of mobile phone in rural China: A case study Hubei, China. Telematics and informatics, 25(3):169-186.

WORLD BANK, 2008. World data bank, Africa infrastructure: National data [viewed 8 November 2017]. Available from: http://databank.worldbank.org/.

ZYL, O.V., ALEXANDER, T., GRAAF, L.D. \& MUKHERJEE, K., 2014. ICTs for agriculture in Africa. The World Bank Report. 